Article

\title{
Preparation and formation mechanism of Al-YNU-1 using highly acid-treated Fe-YNU-1 molecular sieve as a silica source
}

\author{
WANG Pengfei a,b, LI Junfen a , DONG Mei a, QIN Zhangfeng a, WANG Jianguo a, FAN Weibin a,* \\ a State Key Laboratory of Coal Conversion, Institute of Coal Chemistry, Chinese Academy of Sciences, Taiyuan 030001, Shanxi, China \\ b University of Chinese Academy of Sciences, Beijing 100049, China
}

\section{A R T I C L E I N F O}

\section{Article history:}

Received 14 November 2012

Accepted 10 December 2012

Published 20 January 2013

\section{Keywords:}

Al-YNU-1

Hydrothermal synthesis

Acid treatment

Formation mechanism

Fe-YNU-1

\begin{abstract}
A B S T R A C T
Al-YNU-1 molecular sieve was synthesized through the post-synthesis method from highly acid-treated Fe-YNU-1 in the presence of piperidine. The effects of silica sources, structure-directing agents, composition of raw materials, and crystallization conditions on the structure and $\mathrm{Al}$ content of Al-YNU-1 were investigated. Optimizing the $\mathrm{Al}$ and $\mathrm{H}_{2} \mathrm{O}$ amounts in the synthesis mixture, as well as the crystallization time and the acid treatment conditions applied to the as-synthesized lamellar precursors, produced a large increase in the content of $\mathrm{Al}$ in the Al-YNU-1 framework, to nearly double that of a sample prepared using deborated MWW as the silica source. To form Al-YNU-1, it is essential to remove most of the template molecules and framework Al species from the lamellar Al-MWW precursor by acid treatment, and to have a large number of defect sites within the Si source.
\end{abstract}

(C) 2013, Dalian Institute of Chemical Physics, Chinese Academy of Sciences. Published by Elsevier B.V. All rights reserved.

\section{Introduction}

MCM-22 zeolite has a unique layered crystal structure, containing two independent non-intersecting pore systems accessible via 10-MR openings [1]. One system comprises two-dimensional sinusoidal channels with uniform, intralayer 10-MR openings throughout the structure, and the other system is formed by a series of supercages, $0.71 \mathrm{~nm} \times 0.71 \mathrm{~nm} \times$ $1.82 \mathrm{~nm}$, accessible through the elliptic interlayer 10-MR windows. Such a pore system provides interesting structural characteristics, having potential applications in catalytic reactions like benzene alkylation [2], alkane cracking [3], isomerization [4,5], aromatization [6], and the conversion of methanol to hydrocarbons [7]. Nevertheless, the pore openings of MCM-22 are still not large enough to allow processing of bulky reactants. Much work has been done to improve the catalytic performance of MWW zeolites for large molecules by modifying the pore systems through delaminating and pore expanding.

Because of the flexibility and structural diversity of layered zeolites, the precursor MCM-22 can be delaminated or interlayer pillared to obtain more accessible active sites in the interlayer supercages. By swelling the lamellar precursor with surfactant and then pillaring the layers with $\mathrm{SiO}_{2}$ species, MCM-36 was synthesized by researchers at Mobil [8]. Compared with MCM-22, MCM-36 has larger interlayer pore openings, and shows potential for applications in the transformation of bulky reactant molecules. Corma et al. [9] developed a new delaminated material, ITQ-2, with a single layered sheet structure, by swelling and ultrasonic delaminating. ITQ-2 zeolite has a well-defined external surface area, and exhibits high catalytic activity in gasoline cracking. However, its hydrothermal stability is insufficient for practical application in industry, because of structural degradation. Recently, Fan et al. [10,11] proposed a new strategy to expanded the interlayer space from 10-MR to

\footnotetext{
* Corresponding author. Tel: +86-351-4199009; Fax: +86-351-4041153; E-mail: fanwb@sxicc.ac.cn This work was supported by the National Basic Research Program of China (2012CB201403) and the National Natural Science Foundation of China (21273264). DOI: 10.1016/S1872-2067(11)60510-X
} 
12-MR by treating the MWW precursor in a hot acid solution to prepare YNU-1 zeolite. The new interlayer expanded zeolite Al-YNU-1 shows excellent catalytic performance in alkylation and acylation of anisole. However, the framework Al content of the zeolite prepared in this way was very low. On the other hand, through regulating the acid treatment and silylation of the MWW precursor, Wu et al. [12-14] and Inagaki et al. [15] obtained Al-YNU-1 with high framework Al content. However, this method also gave rise to a large amount of extra-framework $\mathrm{Al}$ species and Lewis acidic sites, which led to poor selectivity for certain reactions. In contrast, the expanded Al-YNU-1 synthesized by the methods of Fan et al. [11] had few Lewis acidic sites, and the ratio of strongly acidic sites to weakly acidic sites was up to 18 , with gave this material unique catalytic performance in certain reactions. Nevertheless, it is still a great challenge to find a more effective way to prepare YNU-1 with a higher framework $\mathrm{Al}$ content.

In this work, Al-YNU-1 molecular sieve was synthesized through the post-synthesis method from highly acid-treated Fe-YNU-1 in the presence of piperidine. The effects of silica sources, structure-directing agents (SDA), composition of raw materials, and crystallization conditions on the structure and $\mathrm{Al}$ content of Al-YNU-1 were investigated. The synthesis mechanism was discussed based on characterization of the Al-MWW samples at different synthesis stages.

\section{Experimental}

\subsection{Zeolite preparation}

Al-MWW(P) was prepared using a post-synthesis method. Deborated MWW (DeB-MWW) or highly acid-treated Fe-YNU-1 (DeFe-YNU-1, used as the silica sources for the synthesis of Al-YNU-1) were synthesized by refluxing B-MWW or Fe-MWW samples in $\mathrm{HNO}_{3}$ solution $[10,16]$. The silica source, $\mathrm{Al}$ source (aluminum isopropoxide), structure-directing agent (piperidine, PI or hexamethyleneimine, HMI), ammonium hydroxide (25 wt\%), and distilled water were mixed and stirred at room temperature for $2 \mathrm{~h}$ until a homogeneous phase was obtained. The molar compositions of the gels were within the range $\mathrm{SiO}_{2}$ :
(0-0.025) $\mathrm{Al}_{2} \mathrm{O}_{3}: 1.4 \mathrm{PI}: 0.15 \mathrm{NH}_{4} \mathrm{OH}:(7-30) \mathrm{H}_{2} \mathrm{O}$. After that, the gel was transferred to a Teflon-lined steel autoclave and rotated (20 r/min) at $150{ }^{\circ} \mathrm{C}$ for $1-7 \mathrm{~d}$. The solid product of the precursor Al-MWW(P) was then treated in $\mathrm{HNO}_{3}$ solution $(100 \mathrm{ml}$ liquid per g solid) under different temperatures and for different times. Subsequently, the solid Al-YNU-1 samples were then washed, dried, and calcined at $550{ }^{\circ} \mathrm{C}$ for $6 \mathrm{~h}$. The obtained samples were named Al-YNU-1- $x(\mathrm{~B})$ or Al-YNU-1- $x(\mathrm{Fe})$, where $x$ was the ratio of $\mathrm{Si} / \mathrm{Al}$ in gel. For comparison, a reference sample was also obtained through direct calcination of Al-MWW(P).

\subsection{Characterization}

X-ray diffraction patterns (XRD) were recorded on a Rigaku MiniFlexII X-ray diffractometer with $\mathrm{Cu} K_{\alpha}$ radiation at $30 \mathrm{kV}$ and $15 \mathrm{~mA}$. Nitrogen physisorption measurements were performed at $-196{ }^{\circ} \mathrm{C}$ with a BELSORP-max instrument. Thermogravimetry and differential thermal analysis (TG/DTA) curves were acquired on a Rigaku Thermo plus Evo TG 8120 instrument under air atmosphere at a heating rate of $10{ }^{\circ} \mathrm{C} / \mathrm{min}$. FT-IR spectra was measured on a Bruker Tenson 27 spectrometer with a situ quartz cell. Self-supporting wafer $(30 \mathrm{mg}$ ) was prepared and activated at $500{ }^{\circ} \mathrm{C}$ for $2 \mathrm{~h}$ under vacuum. After cooled to room temperature, the FT-IR spectra of the silanol groups were recorded.

\section{Results and discussion}

\subsection{Al content}

Figure 1 shows XRD patterns of as-synthesized Al-MWW(P), acid treated and further calcined samples obtained from synthesis gels having different $\mathrm{Si} / \mathrm{Al}$ ratios $(\mathrm{Si} / \mathrm{Al}=20-70)$. These samples were synthesized with DeB-MWW as the Si source and hydrothermally crystallized at $150{ }^{\circ} \mathrm{C}$ for $1 \mathrm{~d}$. The silica source, DeB-MWW, exhibits a typical 3D MWW structure (Fig. 1(a)). After crystallization, two new diffraction peaks at $2 \theta$ values of $3.3^{\circ}$ and $6.5^{\circ}$ appear in the XRD patterns of the precursors (Fig. $1(\mathrm{a})$ ), suggesting that the 3D MWW structure has been changed to a 2D MWW layered structure in the present of PI as the SDA.
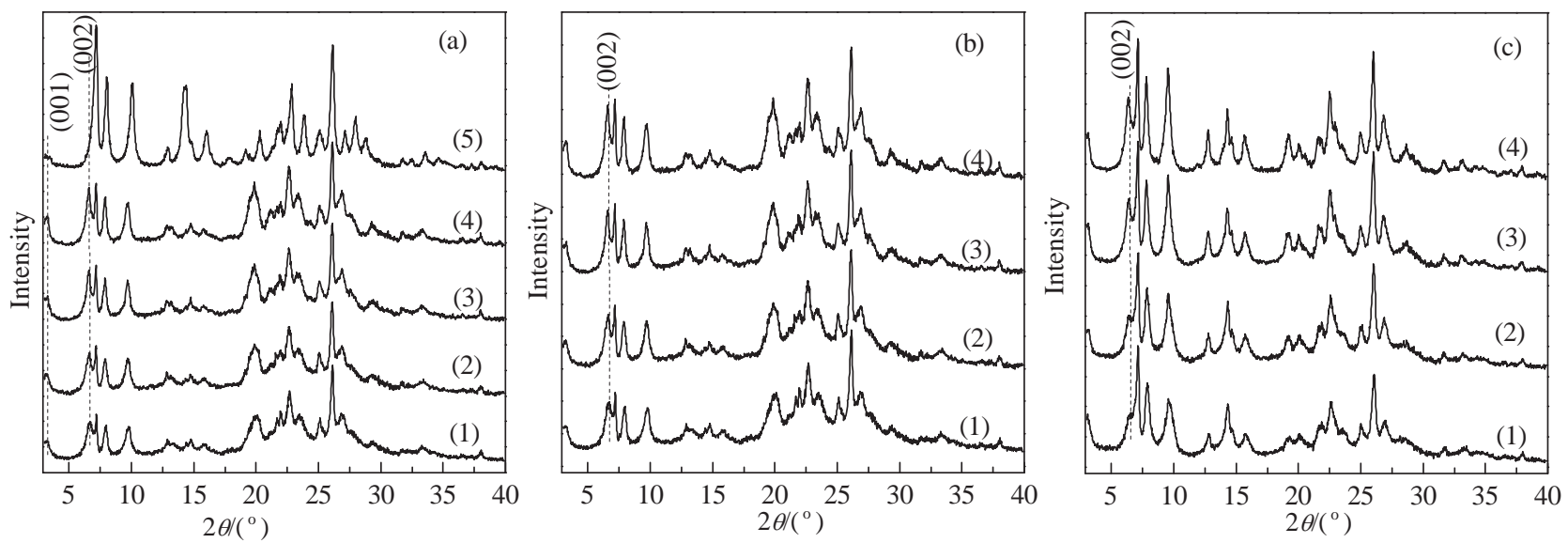

Fig. 1. XRD patterns of as-synthesized (a), acid-treated (b), and further calcined (c) samples obtained from synthesis gels having different Si/Al ratios. (1) $\mathrm{Si} / \mathrm{Al}=20$; (2) $\mathrm{Si} / \mathrm{Al}=25$; (3) $\mathrm{Si} / \mathrm{Al}=40$; (4) Si/Al = 70; (5) DeB-MWW. 
Table 1

Physical properties of Al-YNU-1 samples obtained from synthesis gels with different $\mathrm{Si} / \mathrm{Al}$ ratios.

\begin{tabular}{lcccc}
\hline Sample & $A_{\text {BET }} /\left(\mathrm{m}^{2} / \mathrm{g}\right)$ & $A_{\text {ext }} /\left(\mathrm{m}^{2} / \mathrm{g}\right)$ & $V_{\mathrm{m}} / \mathrm{ml}$ & $\mathrm{Si} / \mathrm{Al}(\mathrm{ICP})$ \\
\hline Al-YNU-1-20(B) & 483 & 171 & 0.13 & 183 \\
Al-YNU-1-25(B) & 474 & 188 & 0.14 & 220 \\
Al-YNU-1-30(B) & 512 & 121 & 0.19 & 275 \\
Al-YNU-1-40(B) & 526 & 104 & 0.20 & 317 \\
Al-YNU-1-75(B) & 520 & 110 & 0.19 & 630 \\
\hline
\end{tabular}

When HMI is used as the SDA in the synthesis of MWW precursor, our previous work suggested that a crystallization time of 4 $\mathrm{d}$ is necessary to obtain a 2D MWW layered structure [11]. This suggests that the smaller PI template molecule can be more easily inserted into the MWW interlayer to expand the interspaces under the crystallization conditions used here. After acid treatment, the layered structure is preserved (Fig. 1(b)). After further calcination at $560^{\circ} \mathrm{C}$, the gel with $\mathrm{Si} / \mathrm{Al}$ ratio of 20 gives a 3D Al-MWW structure, while the gels with higher $\mathrm{Si} / \mathrm{Al}$ ratios have formed Al-YNU-1 (Fig. 1(c)). Moreover, the (002) line intensity increases with increasing $\mathrm{Si} / \mathrm{Al}$ ratio in the synthesis gel.

Table 1 lists the physical properties of Al-YNU-1 samples obtained from synthesis gels with different $\mathrm{Si} / \mathrm{Al}$ ratios. With increasing Si/Al ratio in the gel, the special surface area and micropore volume of the resultant Al-YNU-1 samples also clearly increase. Moreover, the $\mathrm{Si} / \mathrm{Al}$ ratio of Al-YNU-1 is higher than that of the synthesis gel. These mean that the acid treatment removes a large amount of $\mathrm{Al}$ atoms from the precursor, allowing it to form Al-YNU-1 upon calcination [11].

\subsection{Silica source and crystallization time}

Previous work has shown that the YNU-1 structure does not form even with a crystallization time of $6 \mathrm{~d}$ when preparing Fe-YNU-1 through the post-synthesis method. However, properly prolonging the crystallization time can promote the incorporation of the heteroatom into the framework of molecular sieves $[11,16]$. In this work, DeB-MWW and DeFe-YNU-1 samples were used as the silica sources to synthesize YNU-1, and the XRD patterns of the samples obtained using different

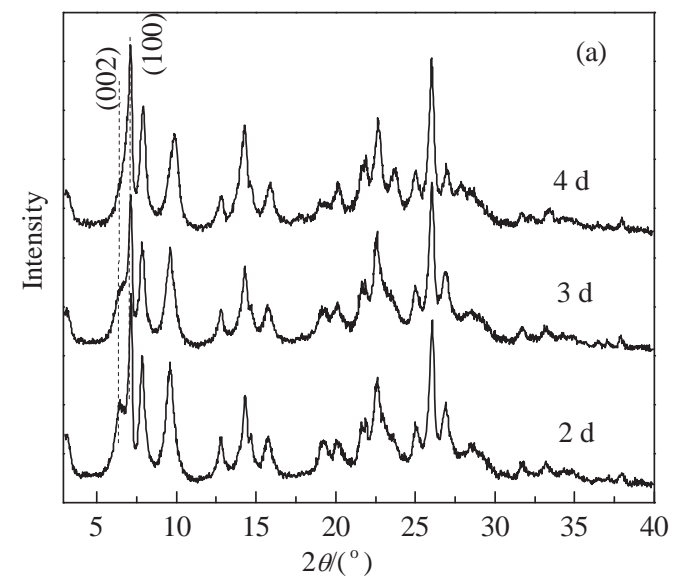

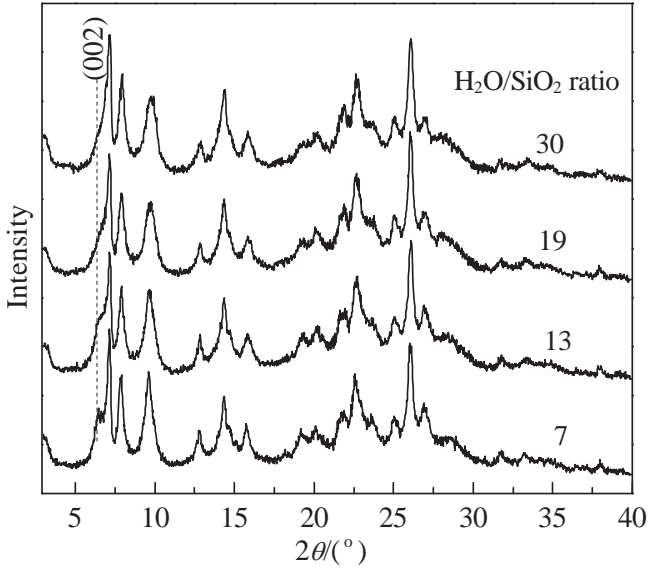

Fig. 3. XRD patterns of Al-YNU-1 samples synthesized from synthesis gels having different $\mathrm{H}_{2} \mathrm{O} / \mathrm{SiO}_{2}$ molar ratios.

crystallization times are compared in Fig. 2. With DeB-MWW as the $\mathrm{Si}$ source, the structure of Al-YNU-1 is obtained when the crystallization time is $2 \mathrm{~d}$ (Fig. 2(a)). With increasing crystallization time to $4 \mathrm{~d}$, the (002) line shifts gradually to higher angle, and merges with the (100) line, implying that the 3D Al-MWW structure has formed. When DeFe-YNU-1 is used as the silica source, the (002) line is clearly observed when the crystallization time is $2 \mathrm{~d}$ and changes little when the crystallization time is prolonged to $4 \mathrm{~d}$. Furthermore, the $\mathrm{Si} / \mathrm{Al}$ ratio of Al-YNU-1 using DeFe-YNU-1 as the Si source and a crystallization time of $4 \mathrm{~d}$ is 118 , about half that of the Al-YNU-1(B) sample with DeB-YNU-1 as Si source crystallized for $1 \mathrm{~d}$. All these results suggest that high framework $\mathrm{Al}$ content can be obtained in Al-YNU-1 by using DeFe-YNU-1 as the silica source.

\section{3. $\mathrm{H}_{2} \mathrm{O}$ content}

The effect of $\mathrm{H}_{2} \mathrm{O}$ content on the quality of Al-YNU-1 structure was investigated for gel compositions of $\mathrm{SiO}_{2}: 0.02 \mathrm{Al}_{2} \mathrm{O}_{3}$ : 1.4PI:0.15 $\mathrm{NH}_{4} \mathrm{OH}:(7-30) \mathrm{H}_{2} \mathrm{O}$. The XRD patterns of the obtained Al-YNU-1 samples are shown in Fig. 3. The $\mathrm{H}_{2} \mathrm{O}$ content has a significant effect on the formation of the Al-YNU-1 structure. With a $\mathrm{H}_{2} \mathrm{O} / \mathrm{SiO}_{2}$ molar ratio of 7 in the synthesis gel, a well

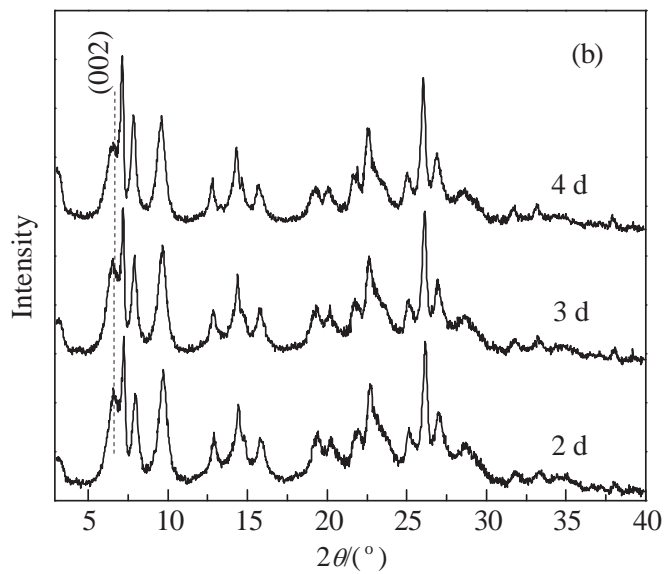

Fig. 2. XRD patterns of Al-YNU-1 samples synthesized using different crystallization times with DeB-MWW (a) or DeFe-YNU-1 (b) as the silica sources (the $\mathrm{Si} / \mathrm{Al}$ ratio in the gel is 25 ). 

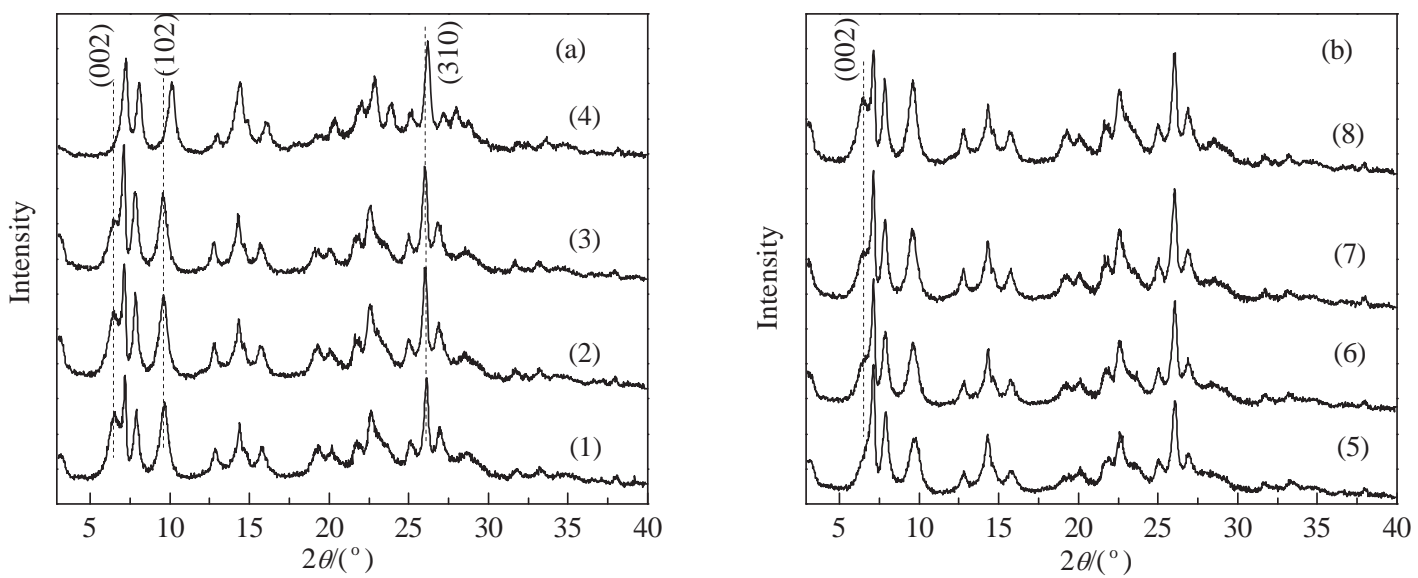

Fig. 4. (a) XRD patterns of the Al-YNU-1 samples obtained through treating with $2 \mathrm{~mol} / \mathrm{L} \mathrm{HNO}_{3}(1), 1 \mathrm{~mol} / \mathrm{L} \mathrm{HNO}_{3}(2)$, and $0.5 \mathrm{~mol} / \mathrm{L} \mathrm{HNO}$ (3) for $1 \mathrm{~d}$ before calcination, and through direct calcination (4); (b) XRD patterns of the Al-YNU-1 samples obtained through treating with $1 \mathrm{~mol} / \mathrm{L} \mathrm{HNO}$ for $4 \mathrm{~h}$ (5), $10 \mathrm{~h} \mathrm{(6),} 16 \mathrm{~h}(7)$, and $24 \mathrm{~h}(8)$ before calcination.

separated (002) diffraction line is observed. With increasing $\mathrm{H}_{2} \mathrm{O}$ content $(>13)$, the (002) diffraction line is shifted to higher angle, suggesting that we obtain a mixture of Al-YNU-1 and Al-MWW. Once the $\mathrm{H}_{2} \mathrm{O} / \mathrm{SiO}_{2}$ molar ratio exceeds 30 , only 3D Al-MWW structure zeolite is obtained.

\subsection{Acid treatment}

Figure 4 illustrates the influence of acid treatment conditions on the Al-YNU-1 structure. Direct calcination without acidic treatment transforms the precursor Al-MWW(P)(Fe) into 3D Al-MWW, as characterized by the three definite diffraction lines in the $2 \theta$ range of $6^{\circ}-11^{\circ}$ and the well separated lines in the $2 \theta$ range of $26.5^{\circ}-30^{\circ}$, with no broad tails on the (310) peak (Fig. 4(a)(4)). However, treating the precursor with nitric acid before calcination leads to different diffraction lines for the calcined samples. Shifts to lower angles of the diffraction lines for (002) and (102) reflections were clearly observed (Fig. 4(a) (1-3)), indicating the formation of Al-YNU-1 structure [10,11]. These results imply that the acid treatment is indispensable for the synthesis of YNU-1 zeolite. Nevertheless, with increasing

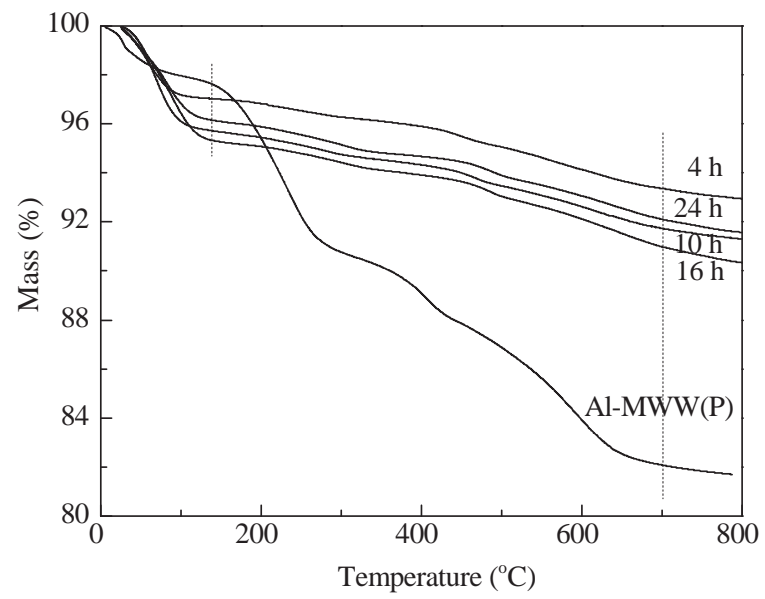

Fig. 5. TG profiles of Al-MWW(P)(Fe) samples treated with 1 mol/L $\mathrm{HNO}_{3}$ for different times.
$\mathrm{HNO}_{3}$ content (Fig. 4(a)) and acid treatment time (Fig. 4(b)), the (002) peak intensity also increases gradually, because of an increase in the quantity of Al-YNU-1(Fe).

The effect of acid treatment on the amount of template molecule (PI) was investigated by TG tests, as shown in Fig. 5. The mass loss of $\mathrm{Al}-\mathrm{MWW}(\mathrm{P})(\mathrm{Fe})$ precursor accounts for the change in mass of $15.5 \%$ observed between $140-700{ }^{\circ} \mathrm{C}$, while the mass loss of the sample in this range after acidic treatment (1 $\mathrm{mol} / \mathrm{L} \mathrm{HNO}_{3}$ ) is only $3.7 \%$. This means that through acid treatment for $4 \mathrm{~h}, 76 \%$ of the PI in the Al-MMW(P)(Fe) was removed. With further increases in the acid treatment time, the amount of PI in the Al-MMW(P)(Fe) sheets does not reduce appreciably. However, increase in the acid treatment time will lead to a decrease in the $\mathrm{Al}$ content in the Al-MMW. The Si/Al ratio is increased from 30 at $4 \mathrm{~h}$ to 98 at $24 \mathrm{~h}$. These findings are consistent with the report that when more framework $\mathrm{Al}$ is removed by acidic treatment, the formation of Al-YNU-1 becomes easier [11].

\subsection{Morphology of sample}

Figure 6 shows a SEM image of the DeB-MWW sample. DeB-MWW is present as typically round, lamellar particles of about $8 \mu \mathrm{m}$ in diameter, made up of stacks of thin platelets (about 0.1-0.5 $\mu \mathrm{m}$ long and 0.05-0.1 $\mu \mathrm{m}$ thick). This morphol-

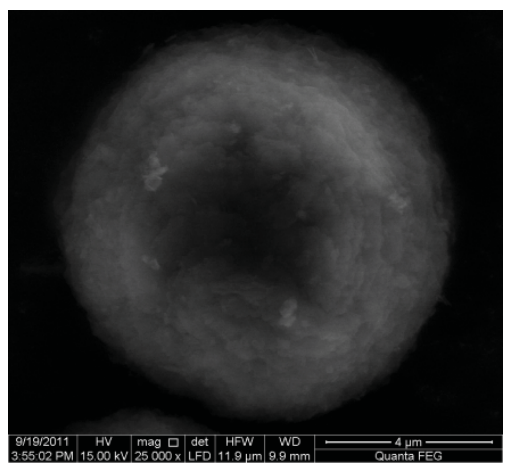

Fig. 6. SEM image of the DeB-MWW sample. 

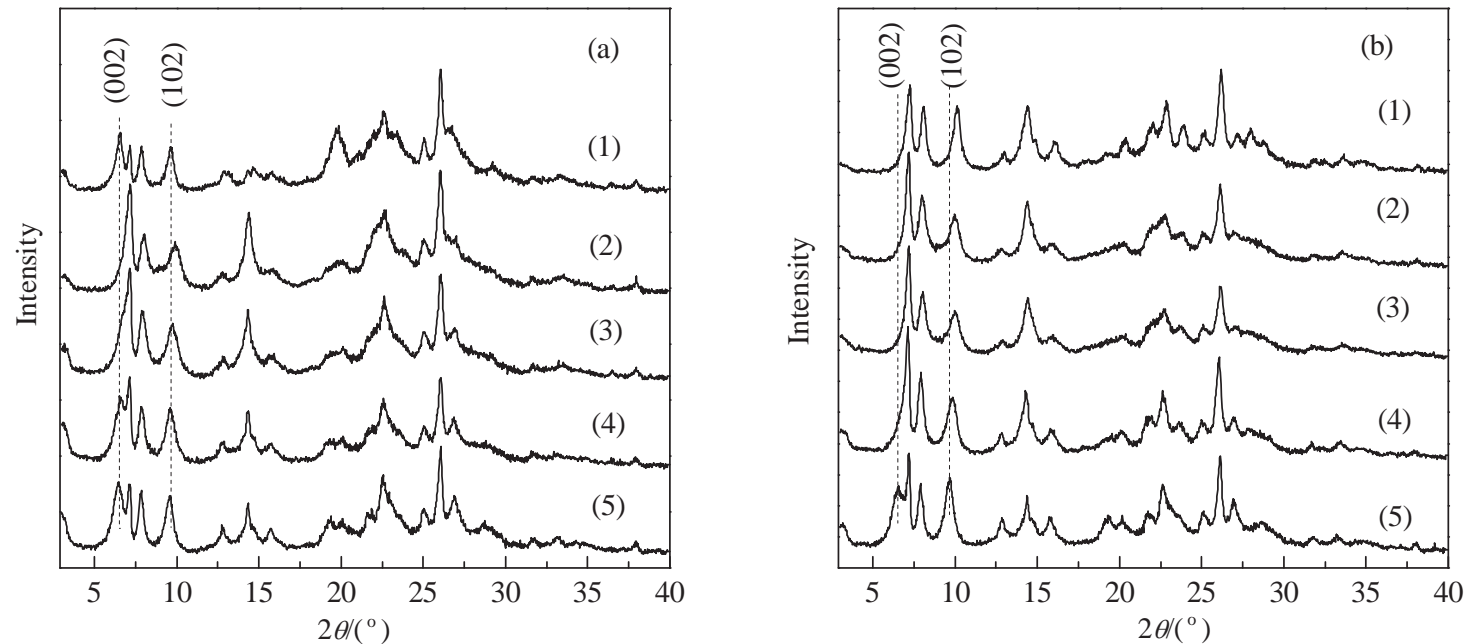

Fig. 7. (a) XRD patterns of samples treated with $\mathrm{H}_{2} \mathrm{O}$ at $100{ }^{\circ} \mathrm{C}$ for $1 \mathrm{~h} \mathrm{(1),} 0.1 \mathrm{~mol} / \mathrm{L} \mathrm{HNO}_{3}$ at $30{ }^{\circ} \mathrm{C}$ for $1 \mathrm{~h}(2), 2 \mathrm{~mol} / \mathrm{L} \mathrm{HNO}{ }_{3}$ at $30{ }^{\circ} \mathrm{C}$ for $1 \mathrm{~d}(3), 2$ $\mathrm{mol} / \mathrm{L} \mathrm{HNO}_{3}$ at $80{ }^{\circ} \mathrm{C}$ for $1 \mathrm{~d}(4)$, and $2 \mathrm{~mol} / \mathrm{L} \mathrm{HNO}_{3}$ at $100^{\circ} \mathrm{C}$ for $1 \mathrm{~d}(5)$; (b) XRD patterns of corresponding calcined samples.

ogy, including the particle size and stacking manner, exhibits little change after subsequent crystallization, acid treatment and calcination (not shown here), suggesting that although the crystallization and acid treatment for post-synthesis may change the microscopic MWW structure into that of DeFe-YUN-1 or Al-YNU-1(Fe), these steps have little influence on the macroscopic morphology.

\subsection{Possible formation mechanism of Al-YNU-1}

To elucidate the formation mechanism of Al-YNU-1, XRD patterns of the samples obtained by treating the Al-MWW(P) precursor under various conditions are displayed in Fig. 7. When the precursor is treated with hot water, little change in the XRD pattern is observed (Fig. 7(a)(1)). Correspondingly, the subsequently calcined sample shows a 3D Al-MWW structure (Fig. 7(b)(1)). However, after treating the Al-MWW(P) with 0.1 $\mathrm{mol} / \mathrm{L} \mathrm{HNO}_{3}$ at $30^{\circ} \mathrm{C}$ for $1 \mathrm{~h}$, the (002) peak disappears or shifts to higher angle (Fig. 7(a)(2)), and about $71 \%$ of the total template PI is removed. The removal of PI molecules alters the parallel arrangement of the Al-MWW(P) sheets so that the in- terlayer space is reduced. By increasing the degree of acid treatment, the (002) diffraction peak (which disappeared after very mild acid treatment) reappears, and its intensity increases with the strength of acid treatment (Fig. 7(a)(3-5)). After calcination of these samples, a mixture of Al-MWW and Al-YNU-1 is obtained (Fig. 7(b)(3,4)). Finally, pure YNU-1 structure is obtained after a deep acid treatment (Fig. 7(a)(5) and Fig. 7(b) (5)).

In addition, ICP results show that higher temperature, higher $\mathrm{HNO}_{3}$ concentration and longer treatment time can remove more Al from the Al-MWW structure $[10,11,16]$. Thus, it can be inferred that the stepwise removal of interlayer templates and succedent $\mathrm{Al}$ atoms at the interlayer site occurs during the acid treatment stage. As a result, many interlayer framework defects are probably generated, and, at the next stage of calcination, the defect sites are then transformed into $\mathrm{Si}-\mathrm{O}-\mathrm{Si}$ bridges between the lamellar layers [17].

The effect of the framework defects on the Al-YNU-1 synthesis is demonstrated, as shown in Fig. 8, by comparing the IR spectra of the hydroxyl stretching vibration region of B-MWW treated with refluxing acid solution either once or three times.
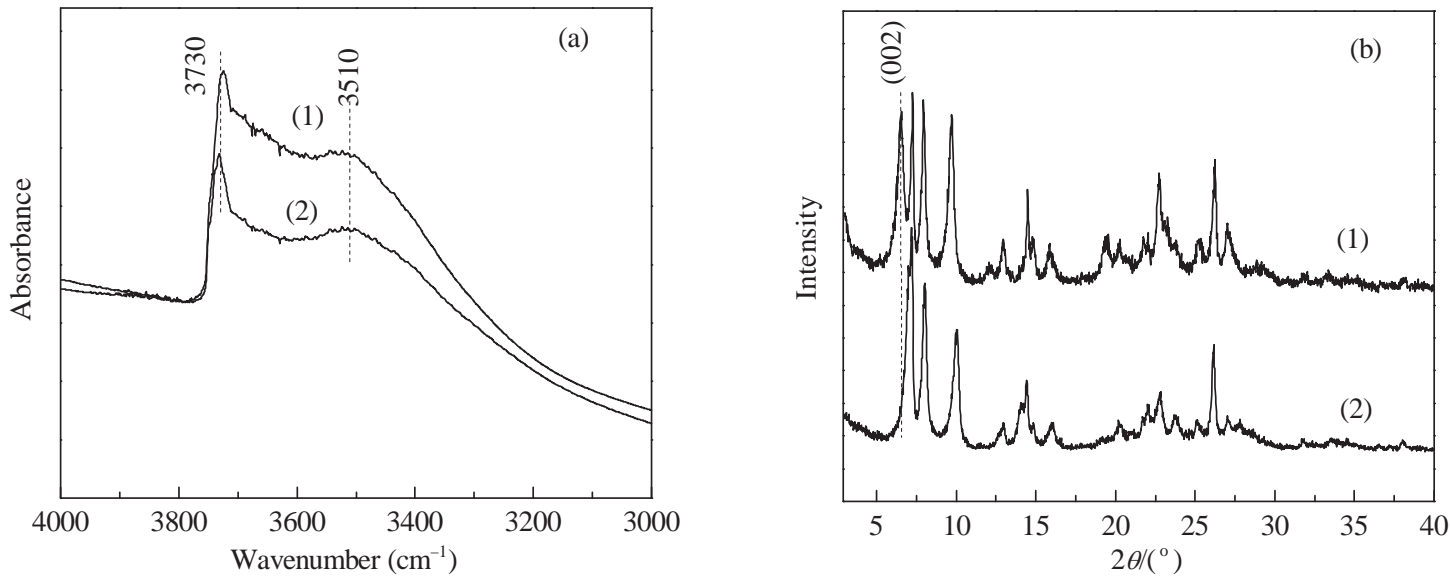

Fig. 8. (a) OH-region IR spectra of DeB-MWW obtained by treating B-MWW with acid once (1) and three times (2); (b) XRD patterns of corresponding YNU-1 samples synthesized from DeB-MWW obtained using B-MWW treated with acid once (1) and three times (2) as a silica source. 


\section{Graphical Abstract}

Chin. J. Catal., 2013, 34: 176-184 doi: 10.1016/S1872-2067(11)60510-X

Preparation and formation mechanism of Al-YNU-1 using highly acid-treated Fe-YNU-1 molecular sieve as a silica source

WANG Pengfei, LI Junfen, DONG Mei, QIN Zhangfeng, WANG Jianguo, FAN Weibin* Institute of Coal Chemistry, Chinese Academy of Sciences

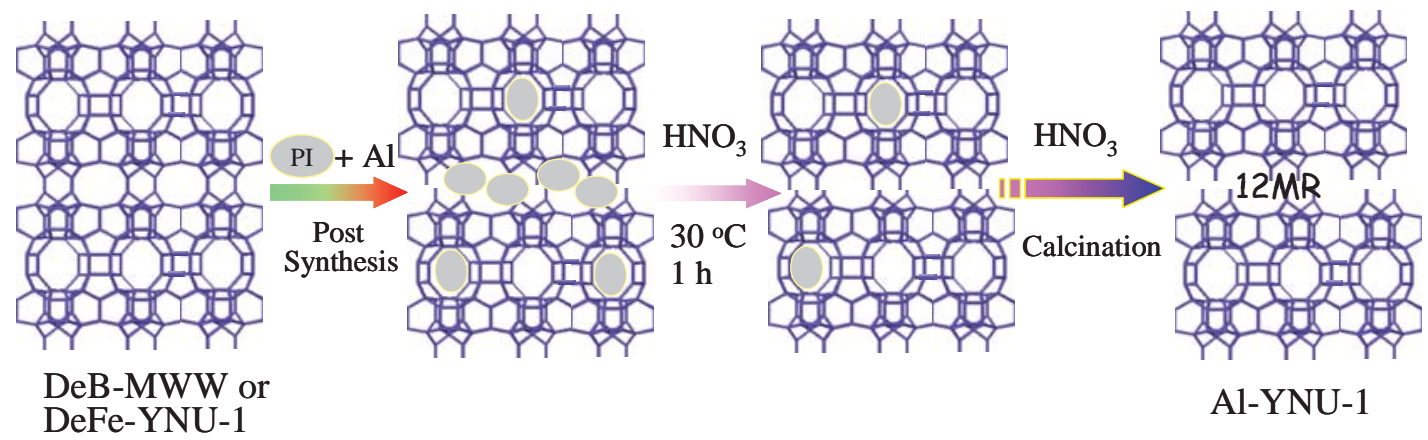

Al-YNU-1 zeolite was post-synthesized using DeFe-YNU-1 as a silica source. In this way, its framework Al content was significantly increased. The chemical composition of the synthesis gel and the acid-treatment conditions of the as-synthesized precursor have great effects on the formation of Al-YNU-1.

The two distinct bands at 3730 and $3500 \mathrm{~cm}^{-1}$ are attributed to external $\mathrm{Si}-\mathrm{OH}$ and silanol nests. The silanol nests should originate from the defect sites formed as a result of the acidic deboronation. When B-MWW treated once with acid is used as the silica source, the resultant sample exhibits intense IR bands at 3730 and $3500 \mathrm{~cm}^{-1}$, showing a large number of defect sites. After calcination, the YNU-1 structure is achieved (Fig. 8(b)(1)). In contrast, in the sample obtained using B-MWW subjected to three acidic treatments, the number of $\mathrm{Si}-\mathrm{OH}$, both external $\mathrm{Si}-$ $\mathrm{OH}$ and internal silanol nests, is reduced (Fig. 8(a)(2)), which can possibly be ascribed to the structure contraction from the harsh acidic treatment. When B-MWW subjected to three acidic treatments is the silica source, the resultant samples show only 3D MWW structure (Fig. 8(b)(2)). Hence, we may deduce that a large number of defect sites in the silica source, as a result of the acid treatment, are essential to obtain YNU-1 zeolite.

\section{Conclusions}

Al-YNU-1 molecular sieve was synthesized through the post-synthesis method from highly acid-treated Fe-YNU-1 in the presence of piperidine. We found that the gel ratio and the crystallization conditions strongly influence the synthesis of Al-YNU-1. High aluminum $(\mathrm{Si} / \mathrm{Al}<20)$ and water contents $\left(\mathrm{H}_{2} \mathrm{O} / \mathrm{Si}>19\right)$ in the synthesis gel and long crystallization time ( $t>4 \mathrm{~d}$ ) are not favorable to the formation of Al-YNU-1. Through optimizing the synthesis conditions, the content of $\mathrm{Al}$ in the Al-YNU-1(Fe) framework is significantly increased ( $\mathrm{Si} / \mathrm{Al}$ = 98), to nearly double that in a sample prepared using deborated $\mathrm{MWW}$ as the silica source $(\mathrm{Si} / \mathrm{Al}=220)$. About $75 \%$ of the template molecules (PI) and a large amount of framework aluminum are removed in a stepwise way by acid treatment. To form Al-YNU-1, it is essential to remove most of the template molecules and framework $\mathrm{Al}$ species in the lamellar Al-MWW precursor during the acid treatment, and to have a large number of defect sites in the Si source.

\section{References}

[1] Lenonwicz M E, Lawton J A, Lawton S L, Rubin M K. Science, 1994, 264: 1910

[2] Fu J Q, Ding C H. Catal Commun, 2005, 6: 770

[3] Okumura K, Hashimoto M, Mimura T, Niwa M. J Catal, 2002, 206: 23

[4] Corma A, Martınez-Triguero J.J Catal, 1997, 165: 102

[5] Shang Y C, Zhang W X, Jia M J, Pan W C, Jiang D Z, Wu T H. Chin J Catal (商永臣, 张文祥, 贾明君, 潘维成, 蒋大振, 吴通好. 催化学 报), 2005, 26: 517

[6] Shu Y Y, Ohnishi R, Ichikawa M. Chem Lett, 2002: 418

[7] Min H K, Park M B, Hong S B. J Catal, 2010, 271: 186

[8] Kresge C T, Roth W J, Simmons K G, Vartuli J C. US 5229341. 1993

[9] Corma A, FornesV, Pergher S B, Maesen Th L M, Buglass J G, Nature, 1998, 396: 353

[10] Fan W B, Wu P, Namba S, Tatsumi T. Angew Chem, Int Ed, 2004, 43: 236

[11] Fan W B, Wei S Q, Yokoi T, Inagaki S, Li J F, Wang J G, Kondo J N, Tatsumi T.J Catal, 2009, 266: 268

[12] Wu P, Ruan J F, Wang L L, Wu L L, Wang Y, Liu Y M, Fan W B, He M Y, Terasaki O, Tatsumi T. J Am Chem Soc, 2008, 130: 8178

[13] Wang L L, Wang Y, LiuY M, Chen L, Cheng S F, Gao G H, He M Y, Wu P. Microporous Mesporous Mater, 2008, 113: 435

[14] Wang Y, Liu Y M, Wang L L, Wu H H, Li X H, He M Y, Wu P. J Phy Chem C, 2009, 113: 18753

[15] Inagaki S, Tatsumi T. Chem Commun, 2009: 2583

[16] Song S S, Wang P F, He Y, Li J F, Dong M, Wang J G, Tatsumi T, Fan W B. Microporous Mesoporous Mater, 2012, 159: 74

[17] Ruan J F, Wu P, Slater B, Terasaki O. Angew Chem, Int Ed, 2005, 44: 6719 


\title{
以深度脱铁Fe-YNU-1分子篮为硅源制备AI-YNU-1及其形成机理
}

\author{
王鹏飞 ${ }^{\mathrm{a}, \mathrm{b}}$, 李俊汾 ${ }^{\mathrm{a}}$, 董 梅 ${ }^{\mathrm{a}}$, 秦张峰 ${ }^{\mathrm{a}}$, 王建国 ${ }^{\mathrm{a}}$, 焚卫斌, ${ }^{\mathrm{a}, *}$ \\ a 中国科学院山西煤炭化学研究所煤转化国家重点实验室, 山西太原030001 \\ 中国科学院大学, 北京100049
}

\begin{abstract}
摘要: 主要研究了以哌啶为模板剂, 深度脱铁的Fe-YNU-1分子笁为硅源, 采用后合成法制备Al-YNU-1分子篮及其形成机理. 通过 考察铝含量、水含量、晶化时间和酸处理条件对形成Al-YNU-1分子篮结构的影响规律, 发现Al-YNU-1分子篮骨架中的Al含量较 以深度脱硼的B-MWW为硅源得到的样品提高了近一倍. 结果表明, Si源中存在大量晶格缺陷位、酸处理脱除Al-MWW层状前驱 中大部分模板剂分子与大量骨架Al是形成Al-YNU-1分子笁的必要条件.
\end{abstract}

关键词: Al-YNU-1; 水热合成; 酸处理; 机理; Fe-YNU-1

收稿日期: 2012-11-14. 接受日期: 2012-12-10. 出版日期: 2013-01-20.

*通讯联系人. 电话: (0351)4199009; 传真: (0351)4041153; 电子信箱: fanwb@sxicc.ac.cn

基金来源: 国家重点基础研究发展计划(973计划,2012CB201403); 国家自然科学基金(21273264).

本文的英文电子版由Elsevier出版社在ScienceDirect上出版(http://www.sciencedirect.com/science/journal/18722067).

\section{1. 前言}

MCM-22分子篮是一类层状结构的微孔材料, 具有 两套独立的、彼此不相连接的10元环孔道体系. 一套是 层间 10 元环孔道, 它与 12 元环超笼 $(0.71 \mathrm{~nm} \times 0.71 \mathrm{~nm} \times$ $1.82 \mathrm{~nm}$ )相连; 另一套为层内二维 10 元环正弦孔道, 与超 笼并不相通 ${ }^{[1]}$. 独特的孔道结构使MCM-22分子篮在苯 烷基化 ${ }^{[2]} 、$ 烷烃裂解 ${ }^{[3]}$ 、异构化 ${ }^{[4,5]}$ 、芳构化 ${ }^{[6]}$ 和甲醇制 烯烃 ${ }^{[7]}$ 等反应中显示出优异的催化性能. 但是, MWW分 子篮较小的孔径限制了其在大分子反应中的应用. 为 此, 许多研究者通过扩孔或层剥离以改善其在大分子反 应中的催化性能.

MCM-22分子篮合成样品为二维层状结构, 为层间 结构调变提供了可能. Mobil公司的研究者 ${ }^{[8]}$ 发现, 该层 状前驱体经碱性表面活性剂溶液溶胀、 $\mathrm{SiO}_{2}$ 交联可制备 成层错堆积的MCM-36分子篮; 与MCM-22相比, 其层间 孔口得到了一定程度的扩张, 在较大分子反应中, 其 12 元 环超笼得到一定程度的利用. 为了进一步改善MCM-22 分子篮在大分子反应中的催化性能, Corma等 ${ }^{[9]}$ 通过对 其层状前驱体进行溶胀、超声剥离处理, 得到具有单层 结构的ITQ-2分子篮. 该分子篮在真空汽油裂解反应中 显示出良好的催化性能. 但是, 这种分子篮含有大量的 晶格缺陷位, 水热稳定性很差, 缺乏工业应用前景. 另外, 在制备过程中, 母体损失严重, 产物收率很低. 为了克服 这些致命缺陷, Fan等 ${ }^{[10,11]}$ 通过对层状前驱体进行酸处理 和调变骨架 $\mathrm{Si} / \mathrm{Al}$ 比, 成功将层间 10 元环孔道扩展为 12 元 环孔道, 制得Al-YNU-1 分子饰, 它在苯甲醚苯甲基化和 酰化反应中具有较高的催化活性 ${ }^{[11]}$. 遗憾的是, 这种分
子篮骨架 $\mathrm{Al}$ 含量很低, 因而提高其骨架 $\mathrm{Al}$ 含量是一个挑 战. 在此背景下, $\mathrm{Wu}$ 等 ${ }^{[2 \sim 14]}$ 和Inagaki等 ${ }^{[15]}$ 通过改变酸处 理路径, 借助硅烷化手段, 得到了骨架 $\mathrm{Al}$ 含量较高的 Al-YNU-1分子篮. 但是, 这些方法得到的样品含有较多 的非骨架 $\mathrm{Al}$, 产生大量的 $\mathrm{L}$ 酸, 从而造成它在某些反应中 选择性很低, 而采用Fan等 ${ }^{[1]}$ 的方法制备的样品不仅 $\mathrm{L}$ 酸 量很少, 而且强酸量与弱酸量之比达到 18 以, 使其具有 独特的催化性能. 因此, 非常有必要发展一种新的制备 Al-YNU-1分子篮的路径, 不仅可以提高其骨架Al含量, 而且能够避免非骨架Al的存在.

本文通过系统研究硅源种类、模板剂结构、原料配 比和晶化条件等对合成产物结构的影响规律, 发现深度 脱铁的Fe-YNU-1 分子篮(DeFe-YNU-1)为硅源不仅可以 在一定程度上提高Al-YNU-1 分子篮骨架的Al含量, 而且 能够对Al-YNU-1分子篮进行可控合成.

\section{2. 实验部分}

\section{1. 样品的制备}

将一定量的哌啶(PI, 99\%, 国药集团化学试剂有限公 司)、去离子水和氨水(25\%)混合均匀后, 加入深度脱喼的 DeB-MWW (Si/B > 200) 或脱铁的DeFe-YNU-1 ( $\mathrm{Si} / \mathrm{B}>$ $1500, \mathrm{Si} / \mathrm{Fe}>2000$ ) 样品, 待摚拌均匀后再加入异丙醇铝 (AR, 国药集团化学试剂有限公司), 并摚拌 $1 \mathrm{~h}$, 然后移入 内祄聚四氟乙烯的合成釜中, 于 $150^{\circ} \mathrm{C}$ 转动晶化. 凝胶摩 尔配比为 $\mathrm{SiO}_{2}:(0 \sim 0.025) \mathrm{Al}_{2} \mathrm{O}_{3}: 1.4 \mathrm{PI}: 0.15 \mathrm{NH}_{4} \mathrm{OH}:(7 \sim 30)$ $\mathrm{H}_{2} \mathrm{O}$. 产物经过滤、洗涤和干燥后得到Al-MWW(P) 前驱 体样品. 再经不同浓度的 $\mathrm{HNO}_{3}$ (液固比为 $100 \mathrm{ml} / \mathrm{g}$ ) 处理 和 $550{ }^{\circ} \mathrm{C}$ 焙烧, 得到 $\mathrm{Al}-\mathrm{YNU}-1-x(\mathrm{~B})$ 或Al-YNU-1- $x(\mathrm{Fe})$ 分 
子篎 $(x$ 为凝胶的 Si/Al比). DeB-MWW和DeFe-YNU-1 分 子篮的制备方法分别详见文献[10,16].

\section{2. 样品的表征}

样品的粉末衍射(XRD)谱在Rigaku Mini flex II X 射线衍射仪上测试, $\mathrm{Cu} K_{a}$ 射线源, 管压 $30 \mathrm{kV}$, 管流 $15 \mathrm{~mA}$, 扫描步长 $0.02^{\circ}$, 扫描速率 $4^{\%} \mathrm{~min}$. 样品的热性质在Rigaku Thermo Plus Evo 8120型热重差热(TG-DTA)分析仪进行 考察, 空气气氛, 室温到 $800^{\circ} \mathrm{C}$, 升温速率 $10^{\circ} \mathrm{C} / \mathrm{min}$. 样品 组成在电感耦合等离子光谱仪 (CP-AES, TJA Autoscan16)上分析. 样品的红外光谱用Bruker Tenson 27仪器 测试, $30 \mathrm{mg}$ 的样品自支撑片在原位红外池中经 $500^{\circ} \mathrm{C}$ 真 空处理 $2 h$, 室温采谱.

\section{3. 结果与讨论}

\section{1. $\mathrm{Al}$ 含量的影响}

图1(a)为以DeB-MWW为硅源、添加不同 $\mathrm{A} 1$ 量、 150 ${ }^{\circ} \mathrm{C}$ 水热晶化 $1 \mathrm{~d}$ 得到样品的 XRD谱. 由此可见, 样品在 $6.54^{\circ}$ 处出现了对应于 $(002)$ 晶面的衍射峰, 表明具有 $3 \mathrm{D}$ 结构的DeB-MWW在不同 $\mathrm{Al}$ 含量体系中均可转变为 $2 \mathrm{D}$ 层状前驱体 $\mathrm{Al}-\mathrm{MWW}(\mathrm{P})$; 而同样条件下, 以六次亚甲基 亚胺(HMI) 为模板剂时, 需晶化 $4 \mathrm{~d}$ 才能形成这样的结 构 $^{[11]}$, 表明分子直径较小的PI分子更易插入MWW分子 篎层间结构中. 这些 $2 \mathrm{D} \mathrm{Al}-\mathrm{MWW}(\mathrm{P})$ 样品经 $\mathrm{HNO}_{3}(2$ $\mathrm{mol} / \mathrm{L}$ ) 处理后, 仍保留层状结构 (见图 $1(\mathrm{~b})$ ), 但再经 $560^{\circ} \mathrm{C}$ 焙烧后, $\mathrm{Si} / \mathrm{Al}$ 比为 20 的凝胶得到样品的(002)衍射峰强度 大幅减弱, 表明其转变为 $3 \mathrm{D} \mathrm{Al}-\mathrm{MWW}$ 结构, 而其它样品 则转化为Al-YNU-1 分子篎( 见图1(1)), 说明 $\mathrm{Al}$ 含量较低 时有利于Al-YNU-1 分子篮的形成.

表 1 为不同 $\mathrm{Al}$ 含量凝胶合成样品的物性参数. 由表 可见, 增加凝胶中 $\mathrm{Al}$ 含量可以适度提高Al-YNU-1 分子篮 骨架中的 $\mathrm{Al}$ 含量, 但孔体积减小, 比表面积略有下降, 而 外比表面积增加. Al-YNU-1分子篎的层间孔道为 12 元 环, 而3D Al-MWW层间孔道为10元环, 由图1可见, 较高 $\mathrm{Al}$ 含量凝胶合成的样品中含有的Al-YNU-1分子篮量较 少, 因此, 孔体积较小. 研究表明 ${ }^{[11]}, \mathrm{Al}-\mathrm{MWW}(\mathrm{P})$ 前驱体 只有经过较为苛刻的酸处理, 除去大部分模板剂分子和 骨架Al后才能转化为Al-YNU-1分子篮.

\section{2. 晶化时间和硅源的影响}

前期研究表明,采用后合成法制备Fe-YNU-1 分子篮 时, 当其晶化时间达到 $6 \mathrm{~d}$ 时, 不能形成YNU-1 结构 ${ }^{[16]}$, 但 适度延长晶化时间有利于杂原子进入分子篮骨架 ${ }^{[11,16]}$. 图2为分别采用DeB-MWW和DeFe-YNU-1 为硅源, Si/Al
$=25$ 时, 凝胶在不同晶化时间得到样品的XRD谱. 由图 可见, 以DeB-MWW为硅源时, 晶化时间少于 $2 \mathrm{~d}$ 时, 可以 得到 Al-YNU-1 分子篮; 若晶化时间延长到 $4 \mathrm{~d}$ 时, 样品 (002)晶面衍射峰向高角度移动, 逐渐与(100)晶面衍射峰 重叠, 形成3D Al-MWW结构. 但当用DeFe-YNU-1 作为 硅源时, 晶化 $4 \mathrm{~d}$ 仍可得到Al-YNU-1 分子䇻, 其骨架 $\mathrm{Si} / \mathrm{Al}$ 比降至 118, 约是 Al-YNU-1-25(B) 的 1/2, 表明以 DeFe-YNU-1 分子篮为硅源可以大幅提高Al-YNU-1 分 子笚骨架的铝含量(见表1).

\section{3. 水量的影响}

图 3 是凝胶组成为 $\mathrm{SiO}_{2}: 0.02 \mathrm{Al}_{2} \mathrm{O}_{3}: 1.4 \mathrm{PI}: 0.15$ $\mathrm{NH}_{4} \mathrm{OH}$ :(7 30) $\mathrm{H}_{2} \mathrm{O}$ 时, 水含量对所制 $\mathrm{Al}-\mathrm{YNU}-1$ 样品结构 的影响. 结果表明, 合成原料中添加的水量虽然对前驱 体Al-MWW $(\mathrm{P})(\mathrm{Fe})$ 的形成没有明显影响, 但对Al-YNU-1 分子篮结构的形成影响很大. 当凝胶中 $\mathrm{H}_{2} \mathrm{O} / \mathrm{SiO}_{2}=7$ 时, 产物的(002)衍射峰清晰; 增加合成原料中的水量至 $\mathrm{H}_{2} \mathrm{O} / \mathrm{SiO}_{2}>13$ 时, 所得样品(002)晶面衍射峰逐渐变弱, 说 明其中 Al-YNU-1 分子篮的含量逐渐减少; 当 $\mathrm{H}_{2} \mathrm{O} / \mathrm{SiO}_{2}=$ 30 时, 只能得到3D Al-MWW分子篮.

\section{4. 酸处理条件的影响}

图4为酸处理条件对 Al-YNU-1 分子篮形成的影响. 由图可见, 直接焙烧 $\mathrm{Al}-\mathrm{MWW}(\mathrm{P})(\mathrm{Fe})$ 后, 样品于 $2 \theta=$ $6^{\circ} \sim 11^{\circ}$ 处出现 3 个清晰的尖峰, 且在 $26.5^{\circ} \sim 30^{\circ}$ 区间的峰也 清晰可辨, 说明直接焙烧形成 $3 \mathrm{D}$ 结构的 $\mathrm{Al}-\mathrm{MWW}$ 分子 筛. 而先经酸处理再焙烧所得样品(002)晶面衍射峰清 晰可见, 且(102)面衍射峰等略向低角度方向偏移, 形成 Al-YNU-1 分子篮 ${ }^{[10,11]}$. 且随着酸浓度和处理时间的增 加, 样品(002)晶面衍射峰逐渐增强, 表明Al-YNU-1(Fe) 量显著增加.

样品的TG-DTA曲线如图5所示, 在 140 700 ${ }^{\circ} \mathrm{C}$ 之间, 前驱体样品 $\mathrm{Al}-\mathrm{MWW}(\mathrm{P})(\mathrm{Fe})$ 的失重量为 $15.5 \%$, 酸处理 4 $\mathrm{h}$ 样品的失重量为 $3.7 \%$, 说明用硝酸处理 $\mathrm{Al}-\mathrm{MWW}(\mathrm{P})(\mathrm{Fe})$ 前驱体 $4 \mathrm{~h}$, 即可脱除其 $76 \%$ 的模板剂. 进一步延长酸处理时间, 样品的模板剂脱除量不再显著 增加, 但 $\mathrm{Si} / \mathrm{Al}$ 从 $30(1 \mathrm{~mol} / \mathrm{L}, 4 \mathrm{~h})$ 增加到 $98(1 \mathrm{~mol} / \mathrm{L}, 24 \mathrm{~h})$. 研究表明 ${ }^{[11]}$, 酸洗除去的骨架 $\mathrm{A} 1$ 量越多, 越利于形成 Al-YNU-1 分子篮.

\section{5. 晶粒形貌}

图6为合成样品的SEM照片.母体DeB-MWW样品由 长约0.1 0.5 $\mu \mathrm{m}$ 、厚约 $0.05 \sim 0.1 \mu \mathrm{m}$ 的薄片状小晶粒堆积 成直径约为 $9 \mu \mathrm{m}$ 的中心凹型的圆饼状大晶粒组成. 经脱 $B$ 、水热晶化、酸处理和焙烧得到的DeFe-YUN-1和 
Al-YNU-1 $(\mathrm{Fe})$ 样品晶粒大小与堆积方式基本没有发生 变化(照片未给出), 说明这些处理过程虽然改变了 DeB-MWW的层间结构,但对其晶粒形貌影响不大.

\subsection{Al-YNU-1分子篮形成机理探讨}

TG/DTA测试表明, Al-MWW(P)(Fe)在水中沸腾处 理并不能脱除模板剂, 因此, 处理后的样品仍保持前驱体 结构, 焙烧后形成 3D Al-MWW 结构. 但经硝酸 $(0.1$ $\mathrm{mol} / \mathrm{L})$ 在 $30{ }^{\circ} \mathrm{C}$ 处理 $1 \mathrm{~h}$ 可脱除约 $71 \%$ 的模板剂, 并导致层 间结构发生明显变化, $2 \mathrm{D} \mathrm{Al}-\mathrm{MWW}(\mathrm{P})(\mathrm{Fe})$ 前驱体转变成 $3 \mathrm{D} \mathrm{Al}-\mathrm{MWW}$. 只有逐渐增加酸处理温度, 并进一步延长 酸处理时间, 二维层间前躯体结构才会逐渐得以保留, 因 此在 $560{ }^{\circ} \mathrm{C}$ 空气气氛中焙烧 $10 \mathrm{~h}$ 后, 仍保留这样的层间结 构, 从而形成YNU-1分子篮.

ICP和 TG 结果表明, 增加酸浓度和酸处理时间能够 脱除较多的骨架 $\mathrm{Al}$ 和大部分、特别是层间模板剂分子. 这是形成YNU-1分子篮的两个必要条件 ${ }^{[10,11,16]}$. 大量骨 架 $\mathrm{Al}$ 的脱除导致形成大量的晶格缺陷位, 大量模板剂分 子的脱除使层间孔道变得空旷, 从而为无定形 $\mathrm{SiO}_{2}$ 碎片 在层间 $\mathrm{T} 1$ 位发生交联反应提供了可能, 结果造成层间 10 元环孔道转变为 12 元环孔道 ${ }^{[17]}$. 该孔道结构虽然水热 稳定性较差, 但热稳定性较高, 因此, 焙烧后仍可保留下 来, 转为YNU-1 结构. 而用低浓度酸处理或处理时间较 短时, 虽然Al-MWW $(\mathrm{P})(\mathrm{Fe})$ 前驱体中大部分模板剂分子 得以脱除, 但骨架中 $\mathrm{Al}$ 的脱除量较少, 因此, 形成的晶格 缺陷位较少, 不利于 $\mathrm{SiO}_{2}$ 物种在 $\mathrm{T} 1$ 位发生交联反应, 导致 焙烧后得到3D Al-MWW分子笁.

晶格缺陷位的作用可以通过下面的实验得到间接 证实. 图8(a)为B-MWW样品分别经一次酸处理和三次
酸处理后得到DeB-MWW样品的差基FT-IR 谱. 3730和 $3500 \mathrm{~cm}^{-1}$ 处吸收峰分别对应于外表面孤立 $\mathrm{Si}-\mathrm{OH}$ 和以氢 键相互连接的 $\mathrm{OH}$ 巢振动吸收峰. 由图可见, 与脱 $\mathrm{B}$ 三次 得到的DeB-MWW (记为DeB-MWW-3)相比较, 酸处理 脱 B 一次得到的DeB-MWW (记为DeB-MWW-1)的着基 吸收峰明显增强, 表明其骨架中存在较多的晶格缺陷位. 如图8(b)所示, 以DeB-MWW-1 为原料可以制备出结构 完美的Ti-YNU-1; 而以DeB-MWW-3 为原料则只能得到 3D Ti-MWW. 这表明采用后合成法制备YNU-1分子篎 时, 其Si源(如DeB-MWW和DeFe-YNU-1)须有或者在酸 处理层状前躯体过程中创造大量的晶格缺陷位, 才能形 成YNU-1结构.

\section{4. 结论}

采用后合成法制备了Al-YNU-1分子耖, 发现合成原 料的配比和晶化条件对形成Al-YNU-1 分子笁的影响很 大, 凝胶中高铝含量 $(\mathrm{Si} / \mathrm{Al}<20)$ 、高水量 $\left(\mathrm{H}_{2} \mathrm{O} / \mathrm{Si}>19\right)$ 及 长的晶化时间 $(t>4 \mathrm{~d})$ 等不利于合成Al-YNU-1 分子篮. 通过优化合成原料中的铝含量、水量及晶化时间和前驱 体的酸处理条件, 与 DeB-MWW 作为硅源相比, 以 DeFe-YNU-1 分子笁为 $S i$ 源合成的Al-YNU-1(Fe)分子篎 中的 $\mathrm{Al}$ 含量增加一倍. 对不同酸处理程度样品的分析表 明, 层状前躯体中的模板剂分子和骨架铝在酸处理过程 中被逐步脱除. 具有 $3 \mathrm{D} \mathrm{MWW}$ 结构的硅源在水热晶化 转变为 $2 \mathrm{D}$ 层状前躯体和后续酸洗与焙烧过程中其形貌 没有发生明显变化. 酸处理脱除层状前躯体中大部分模 板剂分子和骨架铝及 $\mathrm{Si}$ 源中存在大量晶格缺陷位是形 成YNU-1结构的必要条件, 三者缺一不可. 